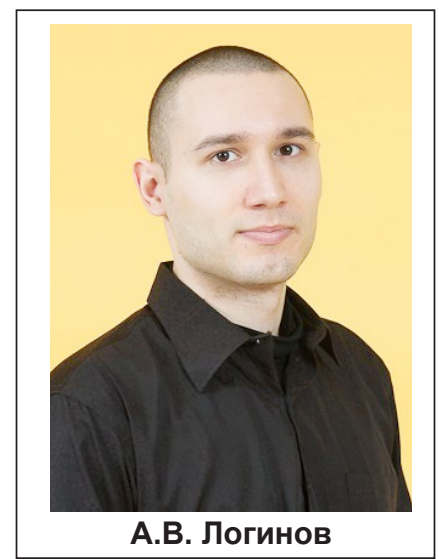

УДк 34.05

\title{
К НЕКОТОРЫМ ПРОБЛЕМАМ СУДЕБНОЙ РЕФОРМЫ В РЕСПУБЛИКЕ АБХАЗИЯ, В КОНТЕКСТЕ ПОСТРОЕНИЯ СОБСТВЕННОЙ СУДЕБНОЙ СИСТЕМЫ В СВЕТЕ РОССИЙСКОЙ СУДЕБНОЙ РЕФОРМЫ
}

\author{
А.В. Логинов
}

\begin{abstract}
Аннотация. Анализируется состояние судебной системы Республики Абхазия в свете конституционной судебной реформы. Проведен анализ основных ошибок данной реформы. Оценивается российский опыт в построении судебной системы, в том числе - и в свете его влияния на Республику Абхазия. Рассматривается критика ЕСПЧ в отношении военных судов в части проблем их независимости от военного командования. Делается вывод о проблеме учреждения Конституционного суда.

Ключевые слова: судебная система Республики Абхазия, Верховный суд, Арбитражный суд, военный суд, городской суд, районные суды, объединение высших судов РФ, судебная реформа.
\end{abstract}

Проходящая в данный момент в Абхазии судебная реформа стала объектом пристального внимания абхазских ученых-правоведов. Необходимость реформирования судебной системы была очевидна уже давно.

С одной стороны, сильная и независимая судебная система должна сделать страну инвестиционно привлекательной, а с другой - повысить уровень соблюдения прав человека, что, теоретически, снизит уровень критики республики со стороны западных ученых-правоведов и политиков и будет способствовать скорейшему признанию независимости Республики Абхазия.

Основными целями судебной реформы были обретение подлинной независимости судебной ветви власти и учреждение Конституционного суда [4, 13]. Попытаемся вкратце проанализировать успехи и недостатки данной судебной рефоромы.

Так, несмотря на закрепленное в ст. 68 Конституции РА положение о том, что правосудие в Абхазии осуществляется исключительно судом - в Абхазии также существуют и квазисудебные органы правосудия, деятельность которых никак не регулируется государством [10, 6]. Впрочем, подобные органы существуют и в Российской Федерации (например, третейские суды), однако их деятельность регулируется законом [1, 8].

На смену Конституционных Законов РА «О судоустройстве в РА» и «Об арбитражных судах РА», Законов РА «О Верховном суде РА» и «О военных судах РА», ранее регулировавших деятель- ность судебной системы, пришел единый Конституционный Закон РА «О судебной власти» [12].

Судебную систему РА составляют: Конституционный суд, Верховный суд, Арбитражный суд, Военный суд, суды районов и г. Сухума.

Конституционный суд является судебным органом конституционного контроля, самостоятельно и независимо осуществляющим судебную власть посредством конституционного судопроизводства.

Стоит отметить, что в Абхазии пока что не начался характерный для России диспут - считать ли Конституционный суд высшим судебным органом. В самом законе суд таковым не называется, равно как и в России (несмотря на расширительное толкование закона Конституционным судом РФ).

Конституционный суд планируется учредить в 2016 г., однако существует ряд обоснованных сомнений в том, что это удастся осуществить в указанный срок [11].

Система общих судов Республики Абхазия представлена верховным, военным, городским и районными судами.

Верховный суд возглавляет систему судов общей юрисдикции и осуществляет следующую деятельность: 1) производит надзор за деятельностью системы судов общей юрисдикции; 2) непосредственно сам отправляет правосудие в качестве суда первой, кассационной и надзорной инстанций и по новым или вновь открывшимся обстоятельствам; 3) дает руководящие разъяс-

`Логинов Анатолий Викторович - аспирант кафедры судебной власти, правоохранительной и правозащитной деятельности Российского университета Дружбы Народов (РУДН) (mr.loginof@mail.ru). 
нения по актуальным вопросам судебной практики деятельности судов общей юрисдикции, а также осуществляет контроль за исполнением судами обшей юрисдикции постановлений Пленума Верховного суда; 4) публикует судебные акты, решает проблемы гласности в области собственной деятельности, в том числе ежегодно публикует доклад о своей деятельности; 5) обращается в Конституционный суд с запросом о конституционности закона, примененного или подлежащего применению в деле, рассматриваемом им в любой инстанции.

В связи с учреждением Конституционного суда у Верховного суда были изъяты полномочия в сорере конституционного контроля. Которыми, к слову, он и так не мог пользоваться по причине отсутствия соответствующих правовых актов, регулирующих деятельность по конституционному правосудию.

Военный суд осуществляет судебную власть в Вооруженных Силах, а также в органах исполнительной власти, в которых законом предусмотрена военная служба.

Впрочем, законодатель устранил пробел в области равенства судов тем, что ныне финансирование Военных судов выведено из-под ведения Министерства обороны и наравне с иными судами подчинено Министерству финансов.

В Республике Абхазия действуют Сухумский городской суд, а также следующие районные суды:

1. Гагрский районный суд;

2. Гудаутский районный суд;

3. Сухумский районный суд;

4. Гулрыпшский районный суд;

5. Очамчырский районный суд;

6. Ткуарчалский районный суд;

7. Галский районный суд.

Впрочем, неясна принципиальная разница между гражданскими и военными судами. Очевидно, не знает ее и законодатель, так как соединил регулирующие деятельность данных судов нормы в одну статью 71 «Районные и военный суды» КЗ РА «О судебной власти».

Стоит отметить, что ЕСПЧ заслуженно критикует деятельность военных судов и ставит под сомнение их «независимость» от военного командования [3].

Арбитражный суд осуществляет правосудие путем разрешения экономических споров и иных подведомственных ему дел.

Как отмечала Ф.А. Квициния, арбитражный суд является единственным звеном судебной системы в сфере экономического правосудия и до настоящего времени работает в качестве двух инстанций: первой и надзорной. Таким образом, субъекты арбитражного процесса лишены права на обжалование судебного акта. Пересмотр ре- шений арбитражного суда осуществляется только в надзорной инстанции [5].

Впрочем, реформа не устранила данного нарушения, так что сегодня в соответствии со ст. 78 КЗ РА «О судебной власти» арбитражный суд рассматривает дела по первой инстанции, осуществляет пересмотр не вступивших в законную силу судебных актов в порядке производства в кассационной инстанции, рассматривает в порядке надзора вступившие в законную силу судебные акты и пересматривает по новым и вновь открывшимся обстоятельствам вступившие в законную силу судебные акты.

Отсутствие системы арбитражных судов в Республике Абхазия приводит к ситуации, когда один и тот же орган сперва принимает постановление, а позже проверяет его на предмет законности [7].

Однако, несмотря на желания абхазских судей создать систему арбитражных судов, следует проанализировать опыт Российской Федерации в области построения системы арбитражных судов. До недавнего времени арбитражные суды заслуженно считались наиболее прогрессивными, однако сегодня очевидно, что их история подошла к концу [2, 9].

В свете глубокого кризиса судебной системы, порожденного противостоянием высших судов Российской Федерации, вылившемся в существование двух подходов к разрешению одних и тех же дел на основании различных правовых норм (ГПК и АПК) в рамках единой судебной системы, в целях реализации идеи единства системы судебной власти и укрепления вертикали власти поглощение Высшего арбитражного суда РФ Верховным судом РФ кажется правомерным.

Однако в Абхазии в данный момент еще не сложился кризис судебной системы в данной сфрере. Впрочем, учитывая уровень влияния российских законов и правоприменительной практики на Республику Абхазия, невозможно отрицать и слияние Арбитражного суда РА с системой судов общей юрисдикции в дальнейшем, по примеру Российской Федерации.

В заключение невозможно не указать на значимость судебной реформы для Республики Абхазия. Центральное место в ней по праву заняло учреждение Конституционного суда. Однако необходимо подчеркнуть, что объем финансовой помощи России для Абхазии сопоставим с бюджетом последней. При этом следует обратить внимание на снижение финансовой помощи, а также на обесценивание рубля, что грозит невозможностью учреждения Конституционного суда РА в срок. Также не построено отдельное здание, предназначенное под нужды Конституционного суда. В числе прочего не решена проблема по кадровому укомплектованию Конституционного суда. 


\title{
ЛИТЕРАТУРА
}

1. Галушкин А.А. Правовое положение третейских судов в Российской Федерации. Правовая инициатива, № 4/2012, 2012 г. [Электронный ресурс] 49e.rusen/node/328(дата обращения: 10.05.2016). 2. Галушкин А.А., Толстых Р.Ю. Арбитражные суды в Российской Федерации: практика, проблематика, концепция развития // Правовая инициатива. 2/2013 [Электронный ресурс] http://49e.ru ru/2013/2/3 (дата обращения: 10.05.2016).

3. Информация о Постановлении ЕСПЧ от 15.09.2015 по делу «Ди липак (Dilipak) против Tурции» (жалоба N 29680/05).

4. Квициния Ф.А. Гарантии независимости судей // дисс. ... к. ю. н. - Ростов-на-Дону, 2007. С. 34.

5. Квициния Ф.А. Арбитражное правосудие в Республике Абхазия: цели, задачи, перспективы развития. [Электронный ресурс] http:// lawyers-abkh.livejournal.com/11436.html (дата обращения: 10.05.2016) 6. Логинов А.B. Обычное право абхазцев: судопроизводство народных судах в доправовой период // Исторические, фрилософские, политические и юридические науки, культурология и искус ствоведение. Вопросы теории и практики. №3-3 (53). 2015. с. 118. Электронный ресурс] http://cyberleninka.ru/article/n/obychnoe-pravoabhaztsev-sudoproizvodstvo-v-narodnyh-sudah-v-dopravovoy-period (дата обращения: 10.05.2016).

7. Логинов А.В. Анализ становления арбитражной юстиции с времен распада СССР и до современных времен на пост советском пространстве: на примере Республики Абхазия и Российской Федерации. [Электронный ресурс] http://познавательный.pфb/all/analiz-stanovlenija-arbitrazhnoi-yustici-s-vremenraspada-sr-i-do-sovremenyh-vremen-na-postsovetskom-prostranstve-naprimere-respubliki-abhazija-i-rosiiskoi-federaci.html (дата обращения: 27.04.2016).

8. Логинов А.В. Основные этапы развития законодательства о третейских судах в России // Правозащитник. 2/2014 [Электронный ресурс] http://pravozashitnik.net/ru/2014/2/11 (дата обращения: 10.05.2016)

9. Логинов А.В. Основные этапы становления судебной системы в Российской Федерации. [Электронный ресурс]: http://sci-article.ru/stat. php?i=1423149498 (дата обращения: 10.05.2016).

10. Логинов А.В. Проблема соотношения действия институтов обычного права в средние века и в современном абхазском обществе // Вестник Владикавказского научного чентра. Том 15. № 1. 2015. С. 32-33. [Электронный ресурс] http://www.vestnik-vnc.ru/ Portals/141/2015-1/2015-1-08.pdf (дата обращения: 10.05.2016).

11. Логинов А.В. Современное состояние судебных систем Российской Федерации и Республики Абхазия в свете последних судебных и конституционных реформ // Евразийский юридический журнал. № 2 (81) 2015. C. 91

12. Логинов А.В. Сравнительно-правовой анализ судебной системы Российской Федерациии и Республики Абхазия на современном этапе // Правоохранительная и правозащитная деятельность в России и за рубежом на современном этапе. Сборник материалов III ежегодной Международной научно-практической конференции / Под редакцией В.В. Гребенникова. - М.: РУДН, 2014. С. 217-220.

13. Логинов А.В. Эволюция конституционной юстиции в Российской Федерации и Республике Абхазия // Исторические, философьские, политические и юридические науки, культурология и искусствоведение. Вопросы теории и практики. 2015. № 4-2 (54). [Электронный pecypc] http://cyberleninka.ru/article/n/evolyutsiyakonstitutsionnoy-yustitsii-v-rossiyskoy-federatsii-i-respublike-abhaziya (дата обращения: 10.05.2016).

\section{TO CERTAIN PROBLEMS OF JURIDICIAL REFORM IN THE REPUBLIC OF ABKHAZIA: IN THE CONTEXT OF DEVELOPMENT OF OWN JURIDICIAL SYSTEM IN THE RELATIONS TO RUSSIAN JURIDICIAL REFORM}

\author{
A.V. Loginov \\ Postgraduate Student, Chair of the judiciary, Law-Enforcement and Human Rights \\ Activity at the Peoples' Friendship University of Russiamr (loginof@mail.ru)
}

\begin{abstract}
The author examines the status of the judicial system of the Republic of Abkhazia in the light of the constitutional judicial reform. The author analyses common mistakes of this reform. It is evaluated the Russian experience in the development of the judicial system, including in the light of its impact on the Republic of Abkhazia. The author also deals the criticism of the ECHR as for military courts in relation to the problems of their independence from the military command. The author construes the problem of the establishment of the Constitutional Court.
\end{abstract}

Keywords: the judicial system of the Republic of Abkhazia, the Supreme Court, the arbitral tribunal, the military court, City Court, the district courts, the high courts of the Russian Federation, the Association of judicial reform.

\section{REFERENCES}

1. Galushkin A.A. Pravovoe polozhenie treteyskikh sudov v Rossiyskoy Federatsii. Pravovaya initsiativa, № 4/2012, 2012 g. [Elektronnyy resurs] 49e. rusen/node/328(data obrashcheniya: 10.05.2016).

2. Galushkin A.A., Tolstykh R. Yu. Arbitrazhnye sudy v Rossiyskoy Federatsii: praktika, problematika, kontseptsiya razvitiya // Pravovaya initsiativa. $2 / 2013$ [Elektronnyy resurs] http://49e.ru/ru/2013/2/3 (data obrashcheniya: 10.05.2016).

3. Informatsiya o Postanovlenii ESPCh ot 15.09.2015 po delu «Dilipak (Dilipak) protiv Turtsii» (zhaloba N 29680/05).

4. Kvitsiniya F.A. Garantii nezavisimosti sudey // diss. ... k. yu. n. - Rostov-na-Donu, 2007. S. 34

5. Kvitsiniya F.A. Arbitrazhnoe pravosudie v Respublike Abkhaziya: tseli, zadachi, perspektivy razvitiya. [Elektronnyy resurs] http://lawyers-abkh.livejournal. com/11436.html (data obrashcheniya: 10.05.2016).

6. Loginov A.V. Obychnoe pravo abkhaztsev: sudoproizvodstvo v narodnykh sudakh v dopravovoy period // Istoricheskie, filosofskie, politicheskie yuridicheskie nauki, kul'turologiya i iskusstvovedenie. Voprosy teorii i praktiki. №3-3 (53). 2015. s. 118. [Elektronnyy resurs] http://cyberleninka.ru/article/n/ obychnoe-pravo-abhaztsev-sudoproizvodstvo-v-narodnyh-sudah-v-dopravovoy-period (data obrashcheniya: 10.05.2016).

7. Loginov A.V. Analiz stanovleniya arbitrazhnoy yustitsii s vremen raspada SSSR i do sovremennykh vremen na postsovetskom prostranstve: na primere Respubliki Abkhaziya i Rossiyskoy Federatsii. [Elektronnyy resurs] http://poznavatel'nyy.rf/all/analiz-stanovlenija-arbitrazhnoi-yustici-s-vremen-raspadasr-i-do-sovremenyh-vremen-na-postsovetskom-prostranstve-na-primere-respubliki-abhazija-i-rosiiskoi-federaci.html (data obrashcheniya: 27.04.2016).

8. Loginov A.V. Osnovnye etapy razvitiya zakonodatel'stva o treteyskikh sudakh v Rossii // Pravozashchitnik. 2/2014 [Elektronnyy resurs] http:// pravozashitnik.net/ru/2014/2/11 (data obrashcheniya: 10.05.2016).

9. Loginov A.V. Osnovnye etapy stanovleniya sudebnoy sistemy v Rossiyskoy Federatsii. [Elektronnyy resurs]: http://sci-article.ru/stat.php?i=1423149498 (data obrashcheniya: 10.05.2016)

10. Loginov A.V. Problema sootnosheniya deystviya institutov obychnogo prava v srednie veka $i$ v sovremennom abkhazskom obshchestve // Vestnik Vladikavkazskogo nauchnogo tsentra. Tom 15. № 1. 2015. S. 32-33. [Elektronnyy resurs] http://www.vestnik-vnc.ru/Portals/141/2015-1/2015-1-08.pdf (data obrashcheniya: 10.05.2016)

11. LoginovA. V. Sovremennoe sostoyanie sudebnykh sistem Rossiyskoy Federatsii i Respubliki Abkhaziya v svete poslednikh sudebnykh i konstitutsionnykh reform // Evraziyskiy yuridicheskiy zhurnal. № 2 (81) 2015. S. 91.

12. Loginov A.V. Sravnitel'no-pravovoy analiz sudebnoy sistemy Rossiyskoy Federatsiii i Respubliki Abkhaziya na sovremennom etape Pravookhranitel'naya ipravozashchitnaya deyatel'nost'v Rossiii iza rubezhom na sovremennom etape. Sbornik materialov Ill ezhegodnoy Mezhdunarodnoy nauchno-prakticheskoy konferentsii / Pod redaktsiey V.V. Grebennikova. - M.: RUDN, 2014. S. 217-220.

13. Loginov A.V. Evolyutsiya konstitutsionnoy yustitsii v Rossiyskoy Federatsii i Respublike Abkhaziya // Istoricheskie, filosofskie, politicheskie yuridicheskie nauki, kul'turologiya i iskusstvovedenie. Voprosy teorii i praktiki. 2015. № 4-2 (54). [Elektronnyy resurs] http://cyberleninka.ru/article/n/ evolyutsiya-konstitutsionnoy-yustitsii-v-rossiyskoy-federatsii-i-respublike-abhaziya (data obrashcheniya: 10.05.2016). 